\author{
Aleksandra Minkwitz \\ ORCID 0000-0002-6994-3045 \\ Adam Mickiewicz University in Poznan \\ Department of Tourism and Recreation \\ aleksandra.minkwitz@amu.edu.pl
}

\title{
TRIPADVISOR AS A SOURCE OF DATA IN THE PLANNING PROCESS OF TOURISM DEVELOPMENT ON A LOCAL SCALE
}

\begin{abstract}
The aim of this article is to answer the question of whether social networking sites can be an effective source of data, useful in the context of local tourism planning. The first part of the article contains a presentation of the role of social media in the tourism industry, a synthetic discussion of the most common topics of research related to the use of social media in tourism, and also characteristic of the TripAdvisor social network, which is the subject of the study. The second part presents the results of a study conducted using the website, covering the 30 most popular hotels, restaurants and tourist attractions in Poznan. The results contain a comment about the risks associated with the analysis of this type of data, as well as possible future directions of research.
\end{abstract}

Keywords: social media in tourism, Web 2.0, TripAdvisor, UGC, local tourism planning.

\section{INTRODUCTION}

Over the past few decades, tourism has become one of the largest and fastest growing industries. It already plays a significant role in stimulating economic growth, in particular through the creation of new jobs, generating revenues from exports as well as infrastructure development (UNWTO 2017). The constantly increasing number of new tourist destinations has resulted in a sudden increase in competitiveness and, as a consequence, created a new challenge for policymakers, the need to move from a somewhat accidental way to set strategic goals to a more thoughtful and orderly approach that allows them to find themselves in dynamically changing conditions (LIU, SIGUAW \& ENZ 2008).

Operation in such a turbulent and chaotic environment (PHILLIPS \& MOUTINHO 2014) requires the use of strategic planning, not only at the level of companies operating on the tourist services market but also among teams working on the development of tourism on a local scale.

One of the main problems faced by planning teams is obtaining data on attendance at tourist attractions. Only some of the owners/organizers of attractions sell tickets which allow the collection of data on the number of visitors. These are mainly museums, amusement parks, events and national parks (KRUCZEK 2016a). Acquiring data on other attractions would require another method which makes it difficult to compare results.

For several years, more and more attention has been paid to the opportunities that social media offer or potentially can give to tourism. The growing interest that is visible is caused by the scale of this phenomenon. Of the nearly 7.6 billion people living in the world, over $42 \%$ are active users of social media (www.wearesocial.com 2018).

Research shows that users are eager to share their experiences in the internet space, including travel experiences (FOTIS, BUHALIS \& ROSSIDES 2012). The entries generated by them (user-generated content) constitute a set of data which, after prior arrangement, can be a valuable source of information on consumer preferences in the tourist market (POLAŃSKA \& WASSILEW 2015). In a rapidly changing society, it is necessary to constantly analyze the generated data streams because it is possible to catch signals indicating the emergence of new trends from the information noise (MCAFEE \& BRYNJOLFSSON 2012).

This article is an attempt to answer the question of whether social networking sites can be an effective source of data useful in the context of local tourism planning. The first part of the article presents the role that social media play in the tourism industry, contains a synthetic discussion of the most frequently 
occurring topics of research related to the use of social media in tourism, and also characterized the Trip Advisor social network, which is the subject of the study. The second part presents the results of a study conducted using the website covering respectively the 30 most popular hotels, restaurants and tourist attractions in Poznan. The research problem covered the socalled new media in tourism. A hypothesis has been put forward that social networking sites can be an effective source of data useful in the context of local tourism planning at the data collection stage. The results of the study were presented using five result maps. The results comment on the risks associated with the analysis of this type of data, as well as possible future directions of research.

\section{SOCIAL MEDIA IN TOURISM}

Social media, as we are currently dealing with, are the most advanced form of implementation whose sources should be sought at the basis of the concept of the internet itself - a network connecting all its users in an interactive way, on the principle of equal access, eliminating the barrier of distance between individual users (PUDEŁKO 2017). Today's internet contains not only static websites but dynamic platforms, where the center of gravity is transferred from one creator to many users. Internet users simultaneously act as consumers and content producers (BERTHON et al. 2012).

The evolutionally change in the way of thinking about the form in which communication in the network takes place is called Web 2.0 (O'REILLY 2005). Thus, Web 2.0 is a certain ideology in the spirit of which space for social media is created. A.M. KAPLAN $\&$ M. HAENLEIN (2010) define this media as 'a group of internet-based applications that build on the ideological and technological foundations of Web 2.0, and that allow the creation and exchange of User Generated Content'.

Social media have become a widely used tool in tourism. There are many tourist portals operating globally that gather consumers and tourism companies and enable communication between them. The most popular web portals of this type include Yelp, $196^{\text {th }}$ in the world ranking of the most visited websites (www.alexa.com 2018) and TripAdvisor (246 ${ }^{\text {th }}$ ). Although both portals are very similar in terms of functionality, there is a noticeable variation in their popularity in particular regions of the world. Yelp is more widely used in the United States, while for Europe it is giving way to TripAdvisor (www.alexa. com 2018).

A literature review has showed that the themes linking social media with the tourism industry oscil- late mainly around issues related to their growing importance in the marketing of tourist destinations (HAYS, PAGE \& BUHALIS 2013, BRZEZIŃSKI \& JASIŃSKI 2014, SZROMNIK 2012), their use in creating the image of a restaurant/hotel (CHAN, GUILLET 2011, KWOK \& YU 2013), their influence on tourist behavior (LIU et al. 2008, MUNAR \& JACOBSEN 2014) and their use in the travel planning process (XIANG \& GRETZEL 2010, FOTIS, BUHALIS \& ROSSIDES 2013).

Although the subject of social media in tourism is widely described in the literature, there are still no studies on the collection of data from websites for tourists, as well as analysis of this data, both quantitative and qualitative.

\section{TRIPADVISOR WEBSITE}

TripAdvisor is an American aggregator of opinion, founded in February 2000 by Stephen Kraufer and Langley Steinert. The site is based on the assumption that tourists planning their trips rely on the opinions of other travellers or treat these opinions as an additional support in making decisions (MIGUÉNS, BAGGIO \& COSTA 2008). Over the past 18 years, the website has collected 661 million reviews of hotels, restaurants and tourist attractions (2018). The offer includes interactive fora for travellers, available in many languages. TripAdvisor sites are available on 49 global markets and collect information about all countries around the world. The average monthly number of users is 456 million people (www.trip advisor.mediaroom.com 2018).

TripAdvisor is a collaborative medium, it works thanks to the cooperation of many individuals who provide opinions on tourist products. On this basis, rankings are created, a common good for the community (HOWE 2009). Website users' opinions on tourist facilities are collected in the form of an assessment on a five-point scale, where 5 is 'excellent' and 1 'terrible'. In addition, each user has the option of adding a short review describing the experience after a visit. The website suggests to reviewers what should be included in a given opinion. Most often the statements relate to activities that can be undertaken in a given place, facilities, additional attractions nearby, the amount of time spent, or the biggest defects. Each opinion can be added in any language, and some of them are automatically translated into other languages.

The credibility of opinions is a matter often discussed in academic discourse (AYEH, AU \& LAW 2013, BANERJEE \& CHUA 2013, ZAJADACZ 2017). Critics accuse the site of adding unfounded opinions, positive - by the interested party, or negative by the competition. It is not possible to determine which opinions are false. 
Due to the threat of abuse, every statement before it is made public, is verified by a company employee. TripAdvisor also takes a number of actions to curb practices, such as a lowering of 1 the ranking, or placing a warning on its site, and also works with law enforcement agencies to detect fraud. In June 2018, the owner of the Italian company PromoSalento, dealing in the sale of opinion-adding, was found guilty of fraud by using a false identity and sentenced to nine months' imprisonment (www.tripadvisor.com).

The website may constitute a source of both quantitative and qualitative data. The portal allows information to be obtained about a specific area, e.g. a city, as well as the type of activity, such as tourist attractions. This data may fill gaps at the stage of primary data collection. Users' opinions are collected on a regular basis, which allows an analysis of changes and is useful at the stage of monitoring and evaluation.

\section{PURPOSES AND METHODS}

The purpose of this article is to present the possibilities offered by TripAdvisor in the scope of obtaining data on the preferences of those visiting the given destinations. This is particularly important at the stage of data collection in tourism development planning on a local scale. The study presented in the article is an attempt to verify these possibilities, although it should be noted that it is only a small segment of the potential that is perceived in the data collected on the site.

The aim of the study is to identify and analyze the location of the most commonly rated tourist locations in Poznan. The research sample included information obtained from TripAdvisor.pl, concerning 30 tourist attractions, 30 hotels and 30 restaurants located in the city. The ranking of the most popular locations was chosen as the criterion of selection for the sample, whereas 'popularity' is measured by the number of reviews, regardless of the level of the assessment obtained. The approach taking into account the highest rated positions was discontinued, due to the fact that the sample collected in this way would almost exclusively contains newly created locations, having several to a dozen or so reviews, and thus had little diagnostic value. The functionality of the Trip Advisor.com website allows sorting by popularity, however the method by which the ranking is determined is unclear, therefore the criterion was omitted. The time range of the survey covers all opinions posted by users of the portal up to January 1, 2018.

Analysis and visualization of the data were made using geoinformation methods including cluster maps, buffer tools (equidistant line - 1000 meter) and Voronoi polygons. On the basis of the collected information, maps showing the users' interest in tourist facilities were drawn up and analyzes were based on topographic data from the area of Poznan (data on Poznan's boundaries, from the Central Office of Geodesy and Cartography, was used for the analysis).

\section{RESULTS}

The attractions identified, using the method described above, along with the corresponding number of reviews, is presented in Table 1 . Table 2 presents the places identified as the most popular as a result of a study conducted by Z. KRUCZEK (2016b) and the Poznań Local Tourist Organization (2016) together with the number of visitors in 2015.

Table 1. The most-rated attractions in Poznan

\begin{tabular}{|c|c|c|}
\hline No. & The name of the attraction & $\begin{array}{c}\text { Number } \\
\text { of } \\
\text { opinions }\end{array}$ \\
\hline 1 & Old Market Square & 1,872 \\
\hline 2 & Lake Maltańskie & 635 \\
\hline 3 & Citadel Park & 501 \\
\hline 4 & Rogalowe Museum & 472 \\
\hline 5 & $\begin{array}{l}\text { Basilica of Our Lady of Perpetual Help and St. } \\
\text { Mary Magdalene }\end{array}$ & 439 \\
\hline 6 & Maltańskie Therms & 425 \\
\hline 7 & Poznan Town Hall & 376 \\
\hline 8 & Poznań Palm House & 333 \\
\hline 9 & St. Peter and Paul Cathedral & 284 \\
\hline 10 & Old Zoo & 276 \\
\hline 11 & Poznan Goats & 256 \\
\hline 12 & Porta Posnania - ICHOT & 238 \\
\hline 13 & Ostrów Tumski & 149 \\
\hline 14 & Miniature train Maltanka & 134 \\
\hline 15 & $\begin{array}{l}\text { Botanical Garden of Adam Mickiewicz } \\
\text { University in Poznan }\end{array}$ & 129 \\
\hline 16 & The National Museum in Poznan & 119 \\
\hline 17 & Lech Brewery & 117 \\
\hline 18 & Tourist Information Center & 116 \\
\hline 19 & Cultural Center ZAMEK & 112 \\
\hline 20 & Poznań Main Railway Station & 110 \\
\hline 21 & Monument of Old Marych & 93 \\
\hline 22 & Archaeological Museum in Poznan & 91 \\
\hline 23 & INEA Stadium & 89 \\
\hline 24 & Franciscan Church & 79 \\
\hline 25 & Monument of Poznan June 1956 & 75 \\
\hline 26 & Blubry 6D - Poznan legends & 58 \\
\hline 27 & Adam Mickiewicz University & 57 \\
\hline 28 & Museum of Musical Instruments & 54 \\
\hline 29 & Monument to the Enigma Slayers & 52 \\
\hline 30 & Sołacki Park & 52 \\
\hline
\end{tabular}

Source: author.

It should be noted that data from Table 2, showing attendance, apply only to ticket sales while omitting all other attractions for which it is not possible to test 
the number of visitors in this way. The time range is also important here - the data in Table 1 covers all the reviews placed on the portal from its beginning until the end of 2017, while the data in Table 2 include the number of visitors only for 2015. There is a large convergence of attractions identified through the Trip Advisor portal and research on the number of visitors.

Table 2. Attendance at tourist facilities in Poznan

\begin{tabular}{|r|l|r|}
\hline No. & \multicolumn{1}{|c|}{ The name of the attraction } & 2015 \\
\hline 1 & Maltańskie Therms & 936900 \\
\hline 2 & Old Zoo & 315135 \\
\hline 3 & Poznań Palm House & 157690 \\
\hline 4 & Porta Posnania - ICHOT & 96276 \\
\hline 5 & Wielkopolska Museum of Independence & 86843 \\
\hline 6 & The National Museum in Poznan & 78500 \\
\hline 7 & Swimming pool in Chwiałka & 72580 \\
\hline 8 & Archaeological Museum in Poznan & 52283 \\
\hline 9 & Mockups of Old Poznań & 50845 \\
\hline 10 & INEA Stadium & 25657 \\
\hline 11 & Archeological Reserve Genius loci & 23533 \\
\hline 12 & Lech Brewery & 21046 \\
\hline 13 & Museum of Environmental Knowledge & 16243 \\
\hline 14 & Museum of Musical Instruments & 11585 \\
\hline 15 & Archdiocesan Museum & 11413 \\
\hline 16 & Dendrological Garden UP in Poznań & 10000 \\
\hline 17 & Fort III & 6850 \\
\hline 18 & Museum of Bamber in Poznań & 4768 \\
\hline 19 & Musical Salon of Feliks Nowowiejski & 2006 \\
\hline 20 & Studio-Museum of Józef Ignacy Kraszewski & 1631 \\
\hline 21 & Presidential Fallout Shelter & 1511 \\
\hline 22 & Kazimiera Iflakowiczówna apartment-studio & 756 \\
\hline
\end{tabular}

Source: author, based on a study conducted by Z. KRUCZEK (2016b, pp. 122-125) and the Poznan Local Tourist Organization report (2016, p. 15).

As a result of the analysis, information was obtained on the location of the most-rated facilities in Poznan (according to users of TripAdvisor). The first of the maps (Fig. 1), presents the location of tourist attractions as well as the railway station and the airport. The most popular attractions in Poznan are mainly located in the central part of the city, in the area of the Old Town. These are both monuments and museums, as well as parks, gardens and sports facilities.

The most frequently rated hotels, restaurants and tourist attractions in Poznan are located in a clear concentration in the city center (Fig. 2). Few tourists decide to go to a hotel far away from the center, and the restaurants located in the central part of Poznan are often chosen as well.

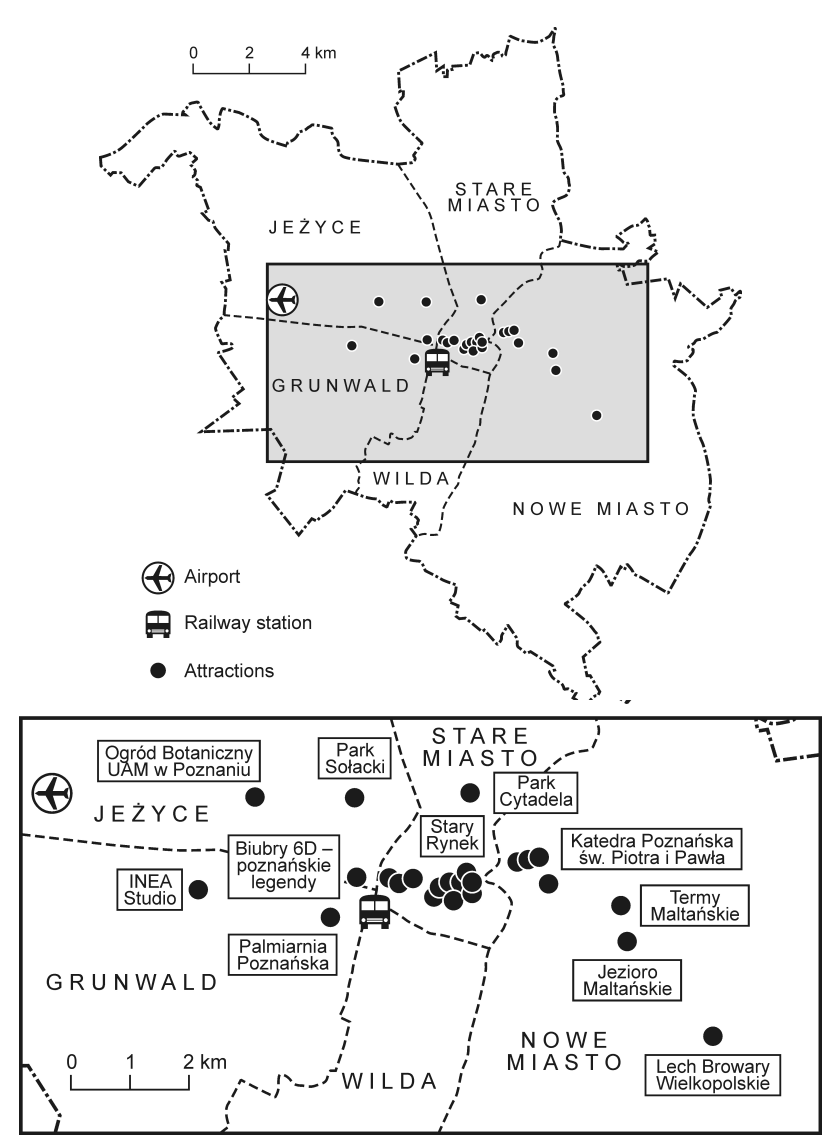

Fig. 1. Location of the most-rated attractions in Poznan Source: author

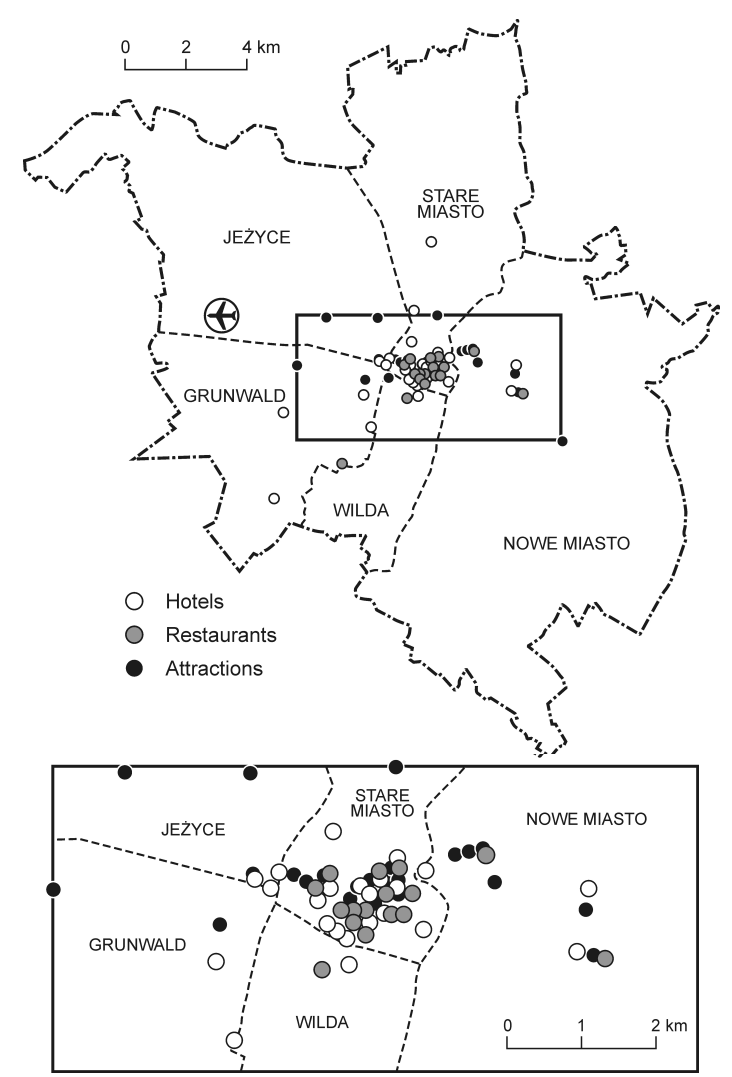

Fig. 2. Most frequently rated hotels, restaurants and attractions in Poznan

Source: author 
The cluster map (Fig. 3) shows that the largest number of eagerly visited attractions is located around the Old Market Square and the surrounding area. As a result of using this method, the area with the highest density is marked on the result map with a darker colour. Few of the attractions selected in the ranking are located outside this zone. The focus of interest is probably due to the large diversity offered by the Old Town area where architectural monuments are located such as tenement houses and the Renaissance town hall, or the parish church, as well as those newly created such as museums and parks.

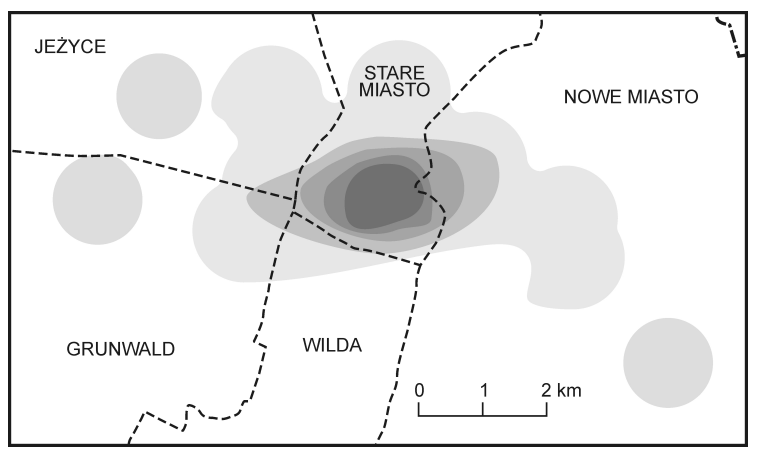

Fig. 3. Cluster map for the most-rated attractions Source: author
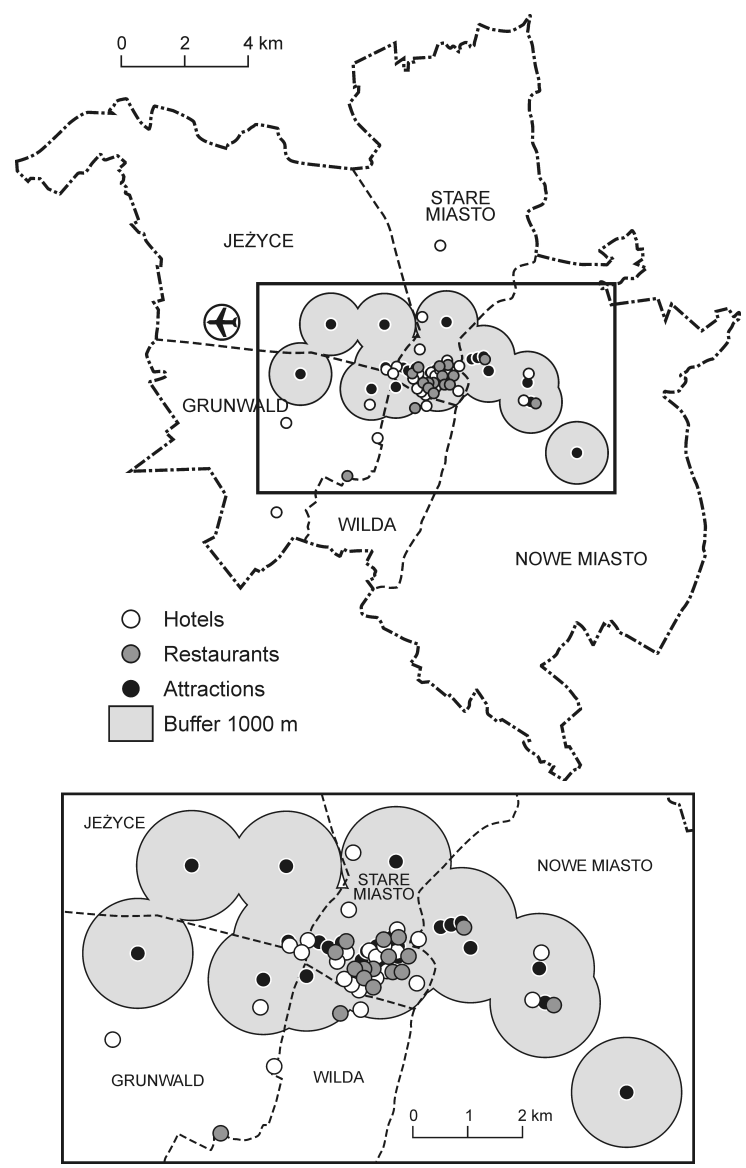

Fig. 4. Buffer $1000 \mathrm{~m}$ for attractions Source: author
Buffer zones created around the most visited attractions (Fig. 4) show that both hotels and restaurants chosen by users are located a short distance away. In the zone covering an area no more than 1000 meters away, there are 29 restaurants. Only four of the 30 hotels in the ranking are located outside the buffer zone.

As a result of using the Voronoi diagram method (Fig. 5), polygons were created - areas where distances from individual attractions are smaller than from others. This makes it possible to believe that a tourist located in a smaller polygon will be more likely to visit attractions located on neighboring polygons. $\mathrm{He} / \mathrm{she}$ will probably also visit restaurants and stay in a hotel located nearby.

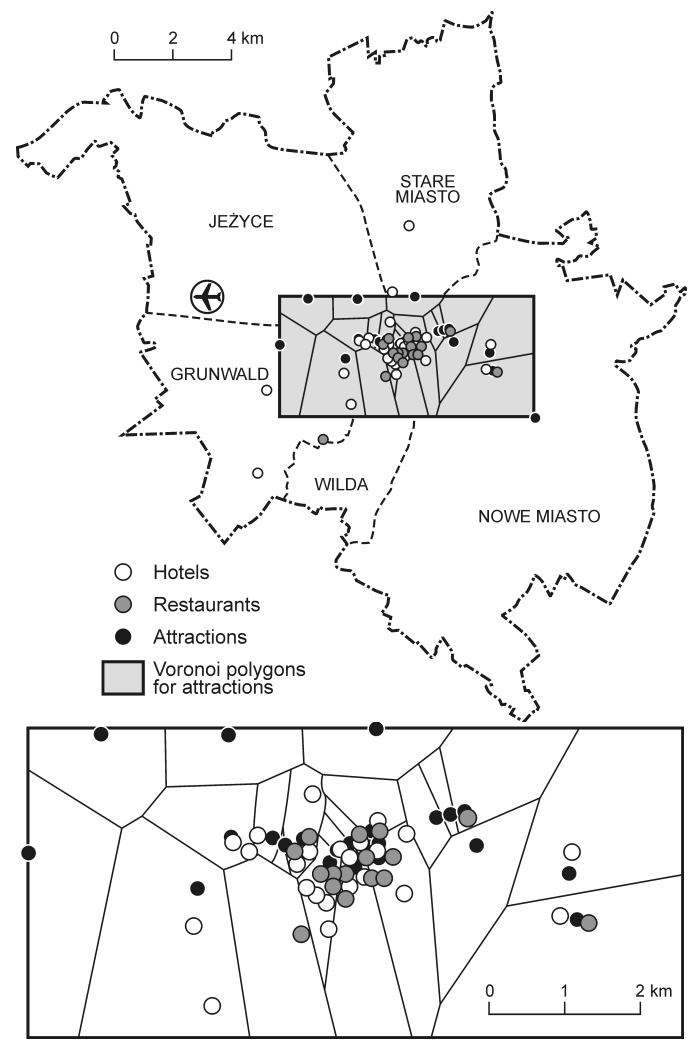

Fig. 5. Voronoi polygons for attractions Source: author

The delimited polygons are clearly smaller for the central part of the city which shows great interest in this area. The entire area identified by this method is a small part of the city and may potentially indicate the boundaries of the area busiest for tourism.

\section{CONCLUSIONS}

The conducted analysis shows the location of sites most frequently chosen by users of the TripAdvisor portal. The areas of greatest density of the most popular attractions as well as areas with potentially 
the busiest number of tourists were determined, assuming that the number of opinions directly translates into the number of visits. The hypothesis regarding the possibility of using a data source such as social media for the needs of local tourism planning has been confirmed.

Comparison of the results with the research conducted so far, using reliable methods, has partially confirmed the effectiveness of the method. Data from social networking sites is more extensive than data collected by other methods and equally considers sites recording the number of visitors and those that do not keep such statistics such as city parks, churches or monuments.

Acquiring data by planning teams is now a big challenge but it can complement information gaps concerning tourism, in the context of a region. The method used is characterized by a high level of universality - it can be used to analyze any tourist destination having a sufficiently high number of ratings. These types of databases, with cyclical updating, allow for a quick identification of emerging trends, in contrast to other methods, e.g. data collection by using a questionnaire, which at the time of use, are already historical. This form of data collection and analysis may be a response to planning problems occurring in the dynamic environment with which we are currently dealing.

Many issues still require detailed elaboration, above all methodologically. The basic one is to simplify the process of data collection and to generate a data bank with a transparent structure and high quality. This requires the creation of many tools to facilitate this process, such as programs that automatically collect data so that it is not capital-intensive and time-consuming. Also, the methods of analyzing this type of data bank are a field that is just taking its first steps and requires a broad diagnosis. Determining the characteristics of the studied group is also an important issue. It should not be presumed that this is a simple reflection of the structure of society. Many questions should be asked here to clarify information about social media users. Who they are? What motivates them to post opinions? Which age groups do they belong to? And many more, allowing customer segments to be represented.

Acquiring data from social networking sites is a difficult task and requires constant learning, modification of already developed methods and development of completely new ones, allowing for obtaining data from other sources. The dynamic development and growing importance of social media has meant that it is impossible to ignore them indifferently. The potential that is hidden in new 'solutions' has already been noticed, but the world is just beginning to get used to the changes that have taken place.

\section{BIBLIOGRAPHY}

AYEH J.K., AU N., LAW R., 2013, “Do we believe in Trip Advisor?" Examining credibility perceptions and online travelers' attitude toward using User-Generated Content, Journal of Travel Research, 52 (4), pp. 437-452.

BANERJEE S., CHUA A.Y.K., 2013, Reliability of reviews on the internet: The case of TripAdvisor, World Congress on Engineering and Computer Science, San Francisco.

BERTHON P.R. et al., 2012, Marketing meets Web 2.0, social media, and creative consumers: Implications for international marketing strategy, Business Horizons, 55 (3), pp. 261-271.

BRZEZIŃSKI S., JASIŃSKI M., 2014, Media społecznościowe w marketingu terytorialnym polskich miast, Marketing i Rynek, 3, pp. 9-17.

CHAN N.L., GUILLET B.D., 2011, Investigation of social media marketing: How does the hotel industry in Hong Kong perform in marketing on social media websites?, Journal of Travel \& Tourism Marketing, 28 (4), pp. 345-368.

FOTIS J., BUHALIS D., ROSSIDES N., 2012, Social media use and impact during the holiday travel planning process, Paper presented at the $19^{\text {th }}$ international conference on information and communication technologies in travel and tourism (ENTER), Jan 25-27, 2012, Helsingborg, Sweden.

HAYS S., PAGE S.J., BUHALIS D., 2013, Social media as a destination marketing tool: its use by national tourism organisations, Current Issues in Tourism, 16 (3), pp. 211-239.

HOWE J., 2009, Crowdsourcing: Why the power of the crowd is driving the future of business, Three Rivers Press, Nowy Jork.

KAPLAN A.M., HAENLEIN M., 2010, Users of the world, unite! The challenges and opportunities of Social Media, Business Horizons, 53 (1), pp. 59-68.

KRUCZEK Z., 2016a, Frekwencja w polskich atrakcjach turystycznych. Problemy oceny liczby odwiedzających, Ekonomiczne Problemy Turystyki, 35 (January), pp. 25-35, https://doi.org/ 10.18276/ept.2016.3.35-02.

KRUCZEK Z., 2016b, Frekwencja w atrakcjach turystycznych w latach 2011-2015, Polska Organizacja Turystyczna, KrakówWarszawa.

KWOK L., YU B., 2013, Spreading social media messages on Facebook, Cornell Hospitality Quarterly, 54 (1), pp. 84-94.

LIU Z., SIGUAW J.A., ENZ C.A., 2008, Using tourist travel habits and preferences to assess strategic destination positioning: The case of Costa Rica, Cornell Hospitality Quarterly, 49 (3), pp. 258-281.

MCAFEE A., BRYNJOLFSSON E., 2012, Big data: The management revolution, Harvard Business Review, 90 (10), pp. 61-67.

MiguÉNS J., BAGGIO R., COSTA C., 2008, Social media and tourism destinations: TripAdvisor case study, Advances in Tourism Research, 26 (28), pp. 26-28.

MUNAR A.M., JACOBSEN J.K.S., 2014, Motivations for sharing tourism experiences through social media, Tourism Management, 43, pp. 46-54.

O'REILLY T., 2005, What is Web 2.0, O'Reilly Media, https:/ / www. oreilly.com/pub/a/web2/archive/what-is-web-20.html.

PHILLIPS P., MOUTINHO L., 2014, Critical review of strategic planning research in hospitality and tourism, Annals of Tourism Research, 48, pp. 96-120.

POLAŃSKA K., WASSILEW A., 2015, Analizy big data w serwisach społecznościowych, Nierówności Społeczne a Wzrost Gospodarczy, 44 (4), pp. 117-128.

PUdEŁKO M., 2017, Prawdziwa historia Internetu (3rd ed.), Itstart, Warszawa. 
SZROMNIK A., 2012, Marketing terytorialny, http://images.ifor mat.pl/195911E5EB/84EC0342-6DCD-4477-84F9-1BB732425 7A8.pdf.

Tripadvisor, 2018, Dochodzenie: kara więzienia za zamieszczanie fatszywych recenzji, https://pl.tripadvisor.com/TripAdvisorIn sights/w4237.

UNWTO, 2017, Tourism Highlights 2017 Edition, https:/ /www.eunwto.org/doi/pdf/10.18111/9789284419029.

XIANG Z., GRETZEL U., 2010, Role of social media in online travel information search, Tourism Management, 31 (2), pp. 179-188.
ZAJADACZ A., 2017, Media społecznościowe w procesie planowania rozwoju turystyki w skali regionalnej, Ekonomiczne Problemy Turystyki, 1 (37), pp. 127-146.

https://www.alexa.com/siteinfo/tripadvisor.com.

https://www.alexa.com/siteinfo/yelp.com. https://www.tripadvisor.com.

https://www.tripadvisor.mediaroom.com.
Article received: 2 October 2018

Accepted:

28 November 2018 